\title{
Association of Reactive Arthritis with Enteric Pathogens
}

\author{
Varsha Gupta, Manpreet Kaur \\ Department of Microbiology, \\ Govt. Medical College and Hospital, Sector 32, Chandigarh.
}

\begin{abstract}
Reactive arthritis (ReA) also known as post infectious arthritis, affects $1-4 \%$ of people days to weeks after being infected by an enteric, urogenital or upper respiratory infection. The most common enteric bacterial pathogens that have been associated with ReA include Salmonella, Shigella, Campylobacter, enterotoxigenic Escherichia coli and Yersinia. It is quite necessary to determine the burden of ReA due to enteric infections using standard criteria. The clinician should investigate for the evidence of previous bacterial infections. In addition, it is very important to carry follow-up studies of patients with enteric infection so as to clarify the association of ReA with enteric pathogens. No curative treatment for reactive arthritis (ReA) exists. Instead, treatment aims at relieving symptoms and is based on symptom severity. Prevention of enteric and genitourinary bacterial infections is the best option.
\end{abstract}

Reactive arthritis (ReA), formerly termed Reiter syndrome(RS), also known as post infectious arthritis, is a spondylo arthropathic disorder characterized by inflammation of the joints and tissues that develops following a bacterial infection of gastrointestinal or genitourinary tract. ${ }^{1,2}$ The classic triad of ReA consists of post-infectious arthritis, nongonococcal urethritis and conjunctivitis.

It is relatively an uncommon disease, affecting $1-4 \%$ of people days to weeks after being infected by an enteric, urogenital or upper respiratory infection. The most common enteric bacterial pathogens that have been associated with ReA include Salmonella, Shigella and Campylobacter. ${ }^{3}$ It was also found to be associated with asymptomatic enteric infections, enterotoxigenic Escherichia coli and Yersinia. ${ }^{4-6}$

Reactive arthritis occurs because of a cellular immune response involving CD8 T-cells. Reactive arthritis is seen more in immunocompromised patients than immunocompetent patients, specifically in those with low CD4 T-cells counts. ${ }^{7}$

\section{Corresponding Author :}

Dr. Varsha Gupta, Professor \& Head, Department of Microbiology, Govt. Medical College and Hospital, Sector 32, Chandigarh, India. Mobile : 9646121571

Email: varshagupta_99@yahoo.com
Reactive arthritis usually begins after an infection involving the gastrointestinal or genitourinary tracts. Initial symptoms include malaise, fatigue, stiffness, pain and arthralgia in the joints of the lower extremities. The onset of this joint pain can occur suddenly and can be accompanied by a fever of over $102^{\circ} \mathrm{F}$, weight loss and inflammatory back pain. Arthritis can occur in association with bacterial infections or can occur few days to weeks after the infection has cleared. Thus, blood, urine and stool cultures should be collected from these patients who present with a suspected gastrointestinal or urogenital bacterial infection to confirm the causative organism. The arthritis often occurs within 2 weeks after the onset of gastroenteritis but the onset can range from 4 to 35 days. Reactive arthritis has been reported as a complication of Salmonella infection in $0.2-7.3 \%$ of cases. ${ }^{8}$ Reactive joint complications triggered by Salmonella are increasingly reported but the outcome and long term prognosis of the patients is incompletely known.

Due to scarcity of Shigella in developed countries, it is the least common of the gastroenteritis inducing organisms which are associated with ReA. A survey of Shigella infected subjects describes an annual incidence of Shigella induced ReA of only 1.3 per million. ${ }^{9}$ It has also been stated that susceptibility of $\operatorname{ReA}$ is strongly associated with HLA-B27. ${ }^{10}$ Some studies showed lack of association with HLA-B27 but a Salmonella outbreak investigation in Australia showed only 2 of 19 subjects with ReA had HLA-B27. ${ }^{11}$ However, there was a 
List of organisms associated with Reactive Arthritis:-

\begin{tabular}{|l|l|}
\hline \multicolumn{2}{|l|}{ Bacterial agents } \\
\hline Salmonella Typhi & Campylobacter jejuni \\
\hline Salmonella Enteritidis & Campylobactercoli \\
\hline Salmonella Typhimurium & Yersinia enterocolitica \\
\hline Shigella flexneri & Clostridium difficile \\
\hline Shigella sonnei & Borrelia \\
\hline Escherichia coli O157 & Chlamydia trachomatis \\
\hline Enterotoxigenic E coli (ETEC) & Hafnia alvei \\
\hline Parasitic agents & \multicolumn{2}{|l}{} \\
\hline Cryptosporidium & Strongyloides stercoralis \\
\hline Giardia lamblia & Schistosoma mansoni \\
\hline
\end{tabular}

study which was conducted to look for the presence and role of any common bacterial antigen among the pathogens isolated from ReA patients. They found a common $30 \mathrm{kDa}$ antigen specifically present among seven arthritogenic enteric bacterial strains belonging to three genera Salmonella, Shigella and Hafnia. Postdysenteric ReA patients' sera showed higher levels of immunoglobulin $\mathrm{G}$, immunoglobulin $\mathrm{M}$ and immunoglobulin $\mathrm{A}$ antibodies against this antigen as compared to the controls. $30 \mathrm{kDa}$ antigen may be a common arthritogenic factor associated with post dysenteric ReA/RS. The association of Hafnia alvei with post-dysenteric ReA was described for the first time. Four cases of mycobacterial ReA had an association with this antigen, suggesting that the arthritogenic antigen of mycobacteria and enteric bacteria may be of a similar nature. $^{12}$

The diagnosis for ReA is based entirely on clinical presentation and physical examination as there is no "gold standard" diagnostic test or imaging finding is available for ReA. Also the patients present with wide range of symptoms, some of which resemble other spondyloarthropathic disorders which leads to difficulty in making diagnosis. ${ }^{1,13}$ Therefore, it is quite necessary to determine the burden of ReA due to enteric infections using standard criteria. The clinician should investigate for the evidence of previous bacterial infections. Even if the gastrointestinal symptoms are not present, the health provider should recommend the stool culture for these patients. Serologic testing for Yersinia, Salmonella and Campylobacter are relatively easy to perform and inexpensive. The use of imaging studies, including magnetic resonance imaging (MRI) is quite helpful to diagnose enteritis that is not clinically obvious. Although ReA can be self-limiting, resolving within 6 months, it has been estimated that up to $63 \%$ of affected patients will develop a chronic form of $\operatorname{ReA} .{ }^{14}$

The treatment of $\operatorname{ReA}$ is still under investigation. Treatment aims at relieving symptoms and is based on symptom severity. Around two thirds of patients have a self-limited course and about 30\% develop chronic symptoms leading to a therapeutic challenge. Nonsteroidal anti-inflammatory drugs (NSAIDs) are currently the mainstay of treatment. Sometimes, joint injections with glucocorticoids and disease modifying antirheumatic drugs (DMARDs) may be beneficial. ${ }^{13}$ The best way is the prevention of enteric and genitourinary bacterial infections including sexually transmitted diseases. Patients presenting with recent onset of arthritic complaints should be enquired about recent diarrheal illness. It is very important to carry follow up studies of patients with enteric infection so as to clarify the association of ReA with enteric pathogens. For the optimal treatment of ReA triggered by enteric pathogens, we have to wait for the results of the ongoing placebo controlled studies. 


\section{REFERENCES}

1. Townes JM. Reactive arthritis after enteric infections in the United States: the problem of definition. Clin Infect Dis 2010;50:247-54.

2. Carter JD, Hudson AP. Reactive arthritis: clinical aspects and medical management. Rheum Dis ClinNorth Am 2009;35:2144.

3. Wu IB, Schwartz RA. Reiter's syndrome: the classic triad and more. J Am Acad Dermatol 2008;59:113-21.

4. Penn H, Keat A. Post-infective arthritis. Medicine 2006;34: 413-6.

5. Locht H, Krogfelt KA. Comparison of rheumatological and gastrointestinal symptoms after infection with Campylobacter jejuni/coli and enterotoxigenic Escherichia coli. Ann Rheum Dis 2002;61:448-52.

6. Hannu T, Mattila L, Nuorti JP, Ruutu P, Mikkola J, Siitonen A, et al. Reactive arthritis after an outbreak of Yersinia pseudotuberculosis serotypeO:3 infection. Ann Rheum Dis 2003;62:866-9.

7. Eapen B. A new insight into the pathogenesis of Reiter's syndrome using bioinformatics tools. International J Dermatol 2003:42,242-3.-
8. Inman RD, Johnston MEA, Hodge M, Falk J, Helewa A. Post dysenteric reactive arthritis. Arthritis Rheum 1988;31:1377-83.

9. Hannu T, Mattila L, Siitonen A, Leirisalo RM. Reactive arthritis attributable to Shigella infection: a clinical and epidemiological nationwide study. Ann Rheum Dis. 2005;64:594-8.

10. Hill Gaston JS, Lillicrap MS. Arthritis associated with enteric infection. Best Pract Res Clin Rheumatol 2003;17:219-39.

11. McColl GJ, Diviney MB, Holdsworth RF. HLA-B27 expression and reactive arthritis susceptibility in two patient cohorts infected with Salmonella Typhimurium. Aust NZJ Med 2000;30:28-32.

12. Singh M, Ganguli NK, Singh H, Deodhar SD, Sethi S, Sharma $\mathrm{M}$. Role of $30 \mathrm{kDa}$ antigen of enteric bacterial pathogens as a possible arthritogenic factor in post-dysenteric reactive arthritis. Indian J Pathol Microbiol. 2013;56:231-7.

13. Sieper J, Rudwaleit M, Braun J, Heijde VD. Diagnosing reactive arthritis: role of clinical setting in the value of serologic and microbiologic assays. Arthritis Rheum 2002;46:319-27.

14. Carter JD. Reactive arthritis: defined etiologies, emerging pathophysiology and unresolved treatment. Infect Dis Clin North Am 2006;20:827-47. 